\title{
List of Charts and Tables
}

\section{CHA R T S}

I:I Real GNP per capita and implicit GNP-deflator I 86r-1972

I :2 Unemployment, I9I I-I97 I

I:3 Real GNP and implicit GNP-deflator:

GNP OECD (five-year averages) : yearly rates of change

I:4 Consumer prices and labour costs: yearly rates of change

I:5 Total investment and private consumption: yearly rates of change

I:6 Fixed investment in manufacturing (tillverkningsindustri)

I :7 Unemployment rate

I :8 Real GNP, actual and full capacity level (potential GNP)

I :9 Gurrent foreign balance and exchange reserves

4:I Schematic picture of typical business cycle in Sweden

4:2 Fluctuations of exports and inventory investment: yearly changes

4:3 Fluctuations in private investment, public investment and dwellings: yearly changes

4:4 Fluctuations in private consumption and total investment: yearly changes

4:5A Balance of payments; components (million Sw.kr.)

4:5B Balance of payments: components (per cent of GNP)

$4: 6$ Some business indicators for Swedish manufacturing

4:7 Official forecast and outcome of GNP: yearly changes 
4:8A Stabilisation policy actions $1945-59$

- schematic picture

4:8B Stabilisation policy actions I 960-7 I

- schematic picture

5:I Impact effect on aggregate demand of fiscal

6:I Effects of investment fund releases in manufacturing industry

IOI

6:2 Labour force taken care of by Labour Market Board

I 06

7:1 Discount rates and interest rates on manufacturing bonds

7:2 Money-GNP ratio

$7: 3$ Fluctuations in money stock and nominal GNP

7:4 Fluctuations in the credit stock to the business sector: yearly rates of change of credit stock from commercial banks and from 'organised' credit market (credit institutes)

8: I Labour market situation and wage increase, industrial workers (all labour costs included) $\quad$ I 54

8:2 Phillips curve for Sweden: workers in manufacturing (based on data 1955-70)

9:I Development of private and public investment, and GNP

9:2 Development of private and public consumption, and GNP

9:3 Development of housing and exports, relative to GNP

I 76

I I : I Lorenz curves for vertical income distribution before tax in Sweden

I I :2 Direct impact of taxes on income distribution of households, 1966

I I:3 Distribution of household income before tax Lorenz curves

I I :4 Distribution of national income between households, firms and the public sector: factor income (i.e. incomes before taxes and transfer payments) 
I I :5 Disposable income and taxes 2 I0

I I :6 Household savings ratio 213

I I :7 Wage costs per unit of output, relative 222

I I :8 Number of merged firms and their share in total employment

Appendix A Real GNP per capita 1862-1970: yearly rates of change

Appendix B Implicit GNP-deflator 1862-1970: yearly rates of change

Appendix G Relative wage levels in different industries, I939-68

Appendix D Unemployment (U), vacancies (V), and shortage of labour (VS), I 949-70.

Second and fourth quarter

T A B L ES

I :A Growth rate $1950-7$ I

$I: B \quad$ The role of exports in the growth process

$I$ :C Importance of the public sector in the Swedish economy

6:A Yearly releases from investment funds

6:B Number of persons in public works, in protected works and retraining (yearly averages)

7:A Effects on investment in manufacturing of investment tax and interest rate policy - as estimated by questionnaire studies

8:A Changes in consumer goods prices $1960-7 \mathrm{r}$, broken down by cost components

8:B Internationalisation of the Swedish economy

9:A Ex post 'elasticities' for public expenditures with respect to GNP

I 78

I I :A Taxable income and disposable income for various groups in 1967 ; average incomes and measure of inequality within groups

I I :B Distribution of disposable income 
I I :c Origin of saving

I I :D Supply of funds from organised credit market (net flows)

216

I I :E Sources of credit to private industry

(flow) 